\title{
Heavy Metals Pollution Characteristics and Health Risk Assessment of Farmland Soils and Agricultural Products in a Mining Area of Henan Province, China
}

\author{
Fawen Zhang ${ }^{1 *}$, Yulong Heㄹ, Changmin Zhao $^{2}$, Yuanbo Kou ${ }^{1}$, Kai Huang ${ }^{1}$ \\ ${ }^{1}$ College of Forestry, Henan Agricultrual University, Zhengzhou, P.R. China \\ ${ }^{2}$ Zhengzhou Environmental Protection Monitoring Center, Zhengzhou Ecological Environment Bureau, \\ Zhengzhou, P.R. China
}

Received: 13 July 2019

Accepted: 12 December 2019

\begin{abstract}
This research focused on soil contamination and the health risks around a mining area in Henan Province of China. Heavy metals contents in farmland soils and agricultural products were analyzed. The results showed that the soils in the mining area had been polluted by heavy metals to different degrees, whereas the average concentrations of heavy metals in farmland soils had exceeded the background value of Henan Province. Cd was the main pollutant element in soils. Agricultural products grown on farmland near the mining area were heavily polluted by $\mathrm{Cd}$ and $\mathrm{Pb}$ and slightly polluted by Cr. Furthermore, the health risk to local inhabitants via food ingestion was assessed based on the United States Environmental Protection Agency (USEPA) health risk assessment model. The results showed that the local inhabitants experience high potential health risks by intake of $\mathrm{Cd}$ and $\mathrm{Pb}$ via consumption of these vegetables. Leafy vegetables had the highest health risks of all agricultural products, whether adults or children, suggesting high health risks by consuming the contaminated agricultural products. Moreover, because children were more sensitively affected by heavy metals from food ingestion, we should pay more attention to monitoring children's health in such areas.
\end{abstract}

Keywords: heavy metals, mining area, health risk assessment

\section{Introduction}

The development of mineral resources has promoted the rapid development of the social economy. However,

*e-mail: zhangfawen@henau.edu.cn mining and mineral processing are regarded as a primary source of heavy metals contamination in the environment due to activities of mineral excavation, ore transportation, smelting, and refining [1-5]. Among all mining wastes, tailings are a solid waste with especially high toxic heavy metals produced in the process of mining, mineral processing and smelting, which are considered the greatest threat to ecological stability due 
to their high content of heavy metals [6-9]. If the tailings are discharged at random, heavy metals will be released into surrounding soils, streams, and groundwater mediated by erosion, weathering, and leaching over a long duration, which may pose serious environmental threats to the surrounding area [10-13]. As a kind of persistent potentially toxic pollutant, heavy metals can easily accumulate in excessive amounts in soils and sediments [14-17]. As excess amounts of metals enter the pedosphere, many nearby farmland mining areas can be contaminated by heavy metals, which threaten the safety of agricultural products and lead to human exposure [18-21]. Heavy metal enrichment in organisms through the food chain will inevitably pose threats to human health and ecosystems, which bring a potential health risk to residents in the vicinity of mining areas [11, 22-24]. Therefore, it is very important to investigate heavy metals contamination in agricultural products and assess the related human health risks.

This study was carried out in Luanchuan County, Henan Province, to evaluate the health risk associate with exposure to heavy metals in soils contaminated by mine tailings. The main goals of the present investigation were: 1) to estimate the environmental impact of heavy metals in samples of farmland soils and agricultural products in a mining area, especially from a nearby tailings reservoir selected according to the preliminary; 2) to assess the pollution risk of heavy metal in soils using risk screening values and risk intervention values; 3 ) to quantify the pollution levels of agricultural products using the method of single-factor pollution index and Nemerow pollution index; and 4) to analyze the non-carcinogenic and carcinogenic risks of heavy metals in agricultural products for adults and children using the health risk assessment model as recommended by the USEPA. The results of this research will not only supply some reference for the risk prevention of heavy metals from harming health, but also provide guidelines for the safe management of soils and agricultural products in the mining area in China.

\section{Materials and Methods}

Study Site Description

The study site is located in Luanchuan County, Henan Province, China. Meanwhile, the district has rich mineral resources of molybdenum, among the top-quality minerals in the nation. The geographic coordinates of the county are east longitude $111^{\circ} 11^{\prime}$ $112^{\circ} 01^{\prime}$ and north latitude $33^{\circ} 39^{\prime}-34^{\circ} 11^{\prime}$. The county has a total area of $2477 \mathrm{~km}^{2}$ and a population of approximately 351,500 people, which belongs to a warm temperate continental monsoon climate zone with an average annual air temperature and precipitation of approximately $12.4^{\circ} \mathrm{C}$ and $750 \mathrm{~mm}$, respectively. The terrain is complex and the zonal soil is brown earth and its organic content is $2-4.5 \%$ and the $\mathrm{pH}$ value is 6.5-7.5.

\section{Sample Collection}

A total 55 samples of farmland topsoil $(0-20 \mathrm{~cm})$ were collected twice in autumn 2017 and 2018. The collection place was the representative farmland sample area with a longer period of cultivation age around the tailings reservoir. From each sample site, five random soil subsamples were taken and mixed into one composite sample referring to HJ/T166-2004

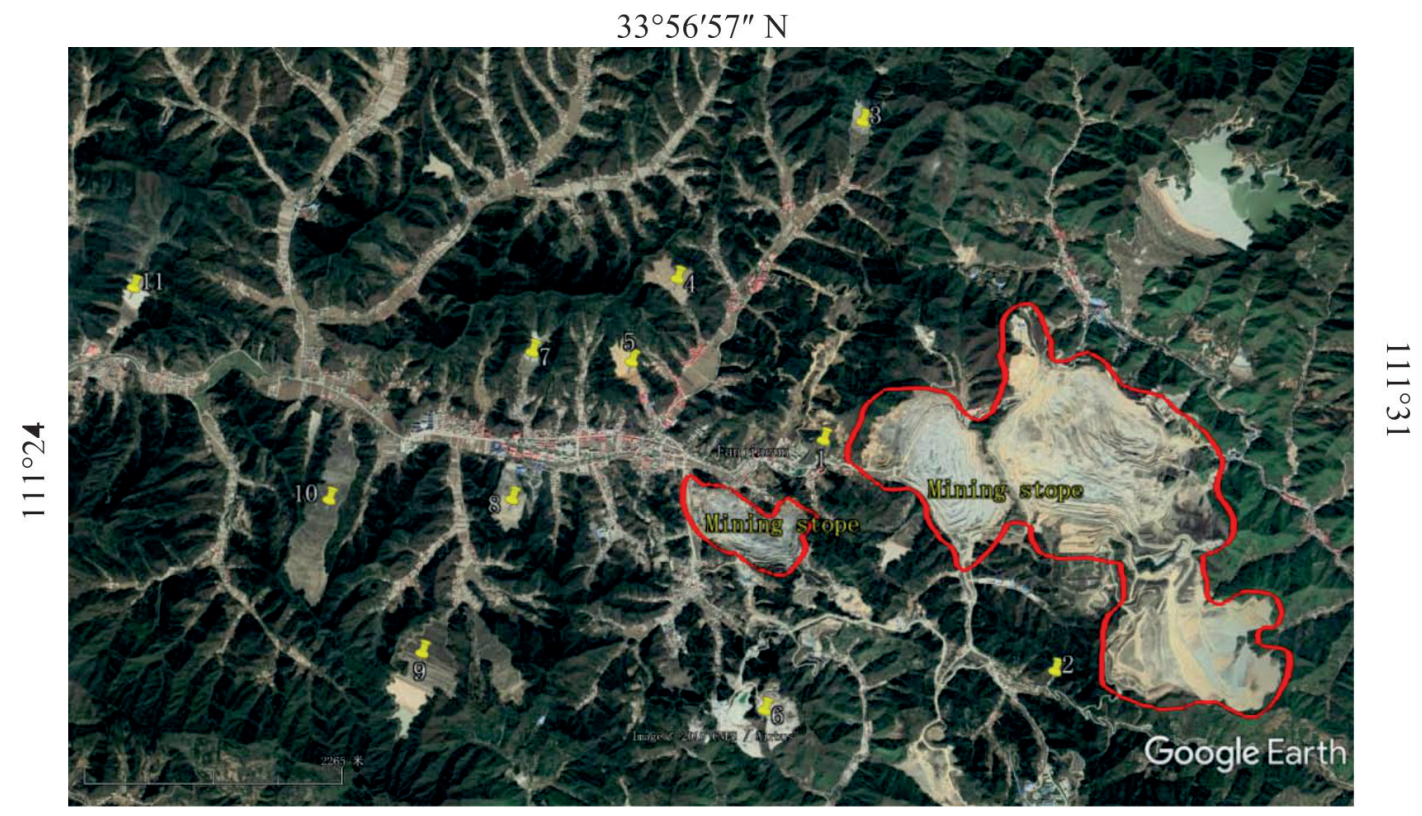

$33^{\circ} 53^{\prime} 34^{\prime \prime} \mathrm{N}$

Fig. 1. Location of the research area and the sampling points in Luanchuan, China. 
a)

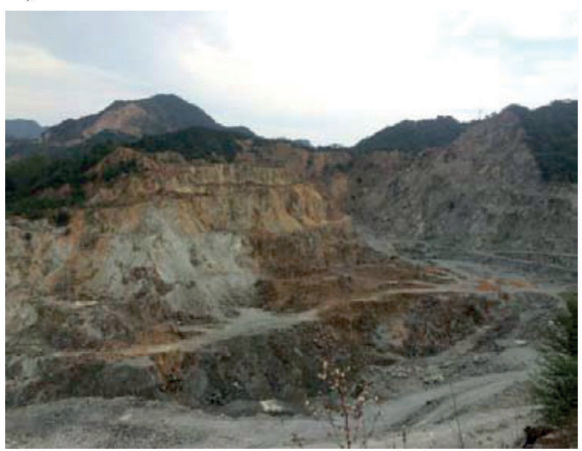

c)

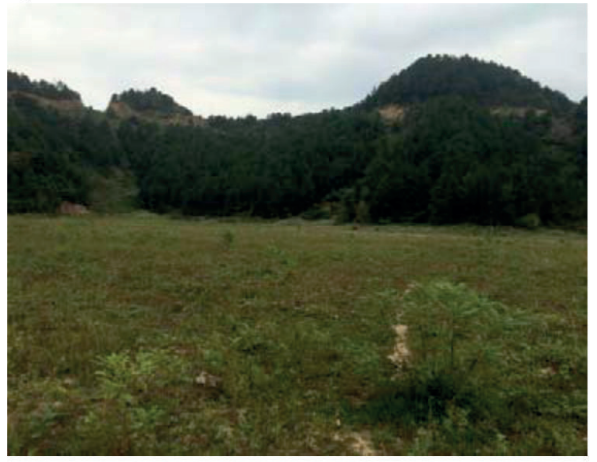

b)

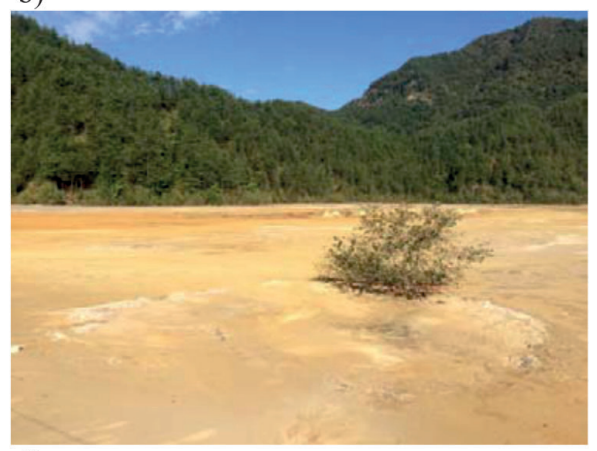

d)

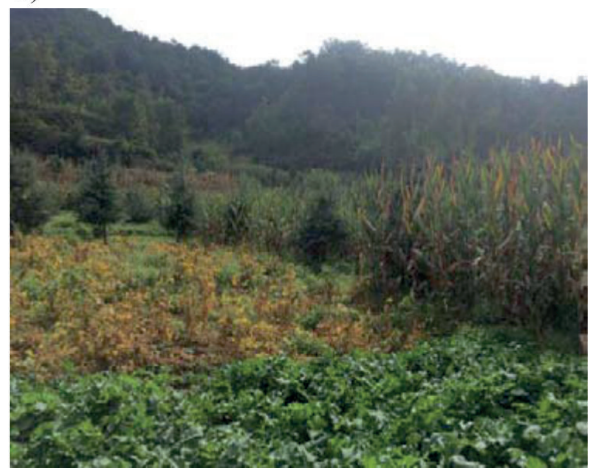

Fig. 2. Photos of typical sampling points.

(China, 2004). The sampling of agricultural products was conducted in autumn 2017. Agronomic plants including cereal crops (maize, whole plant) and various vegetables (edible part) were collected in the studied area depending on the ripening period of the crops. Individual plants at each sampling site were sampled and representative of the naturally occurring species. In the sample area, 2-5 kinds of vegetables and maize were sampled in points corresponding to the soil sampling sites. All types of agricultural products within a distance of $10 \mathrm{~m}$ surrounding a specific sampling location were collected (Figs 1 and 2). A total of 45 agricultural products are divided into the following three categories: 1) leaf vegetables $(\mathrm{N}=25)$ : white cabbage (Brassica napus L.), cauliflower (Brassica oleracea L. var. botrytis L.), cabbage (Brassica oleracea L. var. capitata L.) and scallion (Allium fistulosum L.); 2) underground rhizome vegetables $(\mathrm{N}=12)$ : $\operatorname{carrot}$ (Daucus carota $L$.), white radish (Raphanus sativus L.) and potato (Solanum tuberosum L.); and 3) cereals $(\mathrm{N}=8)$ : maize (Zea mays L.). Sample locations were determined with GPS (Garmin GPS 72H) and environmental conditions for each sample were recorded. Table 1 shows the sample types and locations of the 11 sampling areas.

Table 1. Description of the sampling areas and the samples collected.

\begin{tabular}{|c|c|c|}
\hline Sampling areas & Location & Vegetable samples (N = 45) \\
\hline 1 & $\mathrm{~N} 33^{\circ} 55^{\prime} 14^{\prime \prime}-\mathrm{E} 111^{\circ} 28^{\prime} 19^{\prime \prime}$ & $\mathrm{N}=5$, White cabbage, Cauliflower, Cabbage, Potato, Corn \\
\hline 2 & $\mathrm{~N} 33^{\circ} 54^{\prime} 10^{\prime \prime}-\mathrm{E} 111^{\circ} 29^{\prime} 36^{\prime \prime}$ & $\mathrm{N}=4$, Scallion, Carrot, White radish, Cabbage \\
\hline 3 & $\mathrm{~N} 33^{\circ} 56^{\prime} 44^{\prime \prime}-\mathrm{E} 111^{\circ} 28^{\prime} 32^{\prime \prime}$ & $\mathrm{N}=4$, Corn, Potato, White radish, Cabbage \\
\hline 4 & $\mathrm{~N} 33^{\circ} 55^{\prime} 59^{\prime \prime}-\mathrm{E} 111^{\circ} 27^{\prime} 29^{\prime \prime}$ & $\mathrm{N}=5$, White cabbage, Cauliflower, Cabbage, Carrot, Corn \\
\hline 5 & $\mathrm{~N} 33^{\circ} 55^{\prime} 36^{\prime \prime}-\mathrm{E} 111^{\circ} 27^{\prime} 13^{\prime \prime}$ & $\mathrm{N}=3$, White cabbage, Potato, Corn \\
\hline 6 & $\mathrm{~N} 33^{\circ} 53^{\prime} 58^{\prime \prime}-\mathrm{E} 111^{\circ} 27^{\prime} 59^{\prime \prime}$ & $\mathrm{N}=4$, White cabbage, Cauliflower, Cabbage, White radish \\
\hline 7 & $\mathrm{~N} 33^{\circ} 55^{\prime} 39^{\prime \prime}-\mathrm{E} 111^{\circ} 26^{\prime} 40^{\prime \prime}$ & $\mathrm{N}=4$, White cabbage, Scallion, White radish, Corn \\
\hline 8 & $\mathrm{~N} 33^{\circ} 54^{\prime} 57^{\prime \prime}-\mathrm{E} 111^{\circ} 26^{\prime} 33^{\prime \prime}$ & $\mathrm{N}=2$, Carrot, Scallion \\
\hline 9 & $\mathrm{~N} 33^{\circ} 54^{\prime} 14^{\prime \prime}-\mathrm{E} 111^{\circ} 26^{\prime} 02^{\prime \prime}$ & $\mathrm{N}=5$, White cabbage, Cauliflower, Cabbage, Scallion, Corn \\
\hline 10 & $\mathrm{~N} 33^{\circ} 54^{\prime} 57^{\prime \prime}-\mathrm{E} 111^{\circ} 25^{\prime} 30^{\prime \prime}$ & $\mathrm{N}=4$, Corn, Potato, White radish, Cabbage \\
\hline 11 & $\mathrm{~N} 33^{\circ} 55^{\prime} 57^{\prime \prime}-\mathrm{E} 111^{\circ} 24^{\prime} 22^{\prime \prime}$ & $\mathrm{N}=5$, White cabbage, Cauliflower, Cabbage, Scallion, Corn \\
\hline
\end{tabular}


Table 2. Risk screening and risk intervention values for soil contamination of agricultural land (GB15618-2018) $\left(\mathrm{mg} \cdot \mathrm{kg}^{-1}\right)$.

\begin{tabular}{|c|c|c|c|c|c|}
\hline Risk criteria & Element & $\mathrm{pH} \leq 5.5$ & $5.5<\mathrm{pH} \leq 6.5$ & $6.5<\mathrm{pH} \leq 7.5$ & $\mathrm{pH}>7.5$ \\
\hline \multirow{3}{*}{ Risk screening value } & $\mathrm{Cd}$ & 0.3 & 0.3 & 0.3 & 0.6 \\
\cline { 2 - 6 } & $\mathrm{Cu}$ & 50 & 50 & 100 & 100 \\
\cline { 2 - 6 } & $\mathrm{Cr}$ & 150 & 150 & 200 & 250 \\
\cline { 2 - 6 } & $\mathrm{Pb}$ & 70 & 90 & 120 & 170 \\
\hline \multirow{3}{*}{ Risk intervention value } & $\mathrm{Cd}$ & 1.5 & 2.0 & 3.0 & 4.0 \\
\cline { 2 - 6 } & $\mathrm{Cu}$ & - & - & - & - \\
\cline { 2 - 6 } & $\mathrm{Cr}$ & 800 & 850 & 1000 & 1300 \\
\cline { 2 - 6 } & $\mathrm{Pb}$ & 400 & 500 & 700 & 1000 \\
\hline
\end{tabular}

\section{Determining and Analyzing Samples}

In the laboratory, all the soil samples were homogenized and air-dried in a cool, dark and ventilated place at room temperature. The air-dried topsoil samples were first removed of plant debris, refuse and stones, then crushed and sieved through 100 mesh screens in sequence. The samples were conserved in polyethylene bags at $4^{\circ} \mathrm{C}$ until analysis. All the collected agriculture products were thoroughly washed with tap and deionized water to remove the adhering substrate materials, and separated by edible and non-edible parts, and then treated at $105^{\circ} \mathrm{C}$ for $30 \mathrm{~min}$ to denature all enzymes and $80^{\circ} \mathrm{C}$ for $24 \mathrm{~h}$ to dry out the water contained. During the cleaning and drying procedure, the water content of each sample was also measured. Then they were crushed to a small size and stored in polyethene zip-lock bags for further analysis.

Soil $\mathrm{pH}$ was measured by a $\mathrm{pH}$ meter at a $1: 5(\mathrm{w} / \mathrm{v})$ ratio of soil to distilled water with a glass electrode (INESA PHSJ-3F, China). Soil organic matter (OM) was determined by low temperature external heat potassium dichromate oxidation method [24]. Total concentration of heavy metal was extracted by the $\mathrm{HF}-\mathrm{HNO}_{3}-\mathrm{HClO}_{4}$ digestion method. 1:5 (soil or plant:water) extracts were prepared by shaking $0.5 \mathrm{~g}$ of soil or plant with $25 \mathrm{ml}$ of relevant extractants for $1 \mathrm{~h}$ in a horizontal rotation shaker. These digested samples were then filtered and diluted into $50 \mathrm{~mL}$ volumetric flasks with distilled water $[25,26]$. Samples were filtered under vacuum to eliminate turbidity or suspended substances. The concentrations of various heavy metals in all the digested samples were determined by atomic absorption spectrometry (AAS, TAS-990, China).

\section{Methodology of Contamination and Health Risk Assessment}

\section{Assessment Standard of Soil Contamination}

New soil environmental quality standards (GB156182018) in China were published in 2018, which can be applied to the investigation of soil contamination and the regulation of the maximum concentration levels of heavy metals in agricultural land. The pollution thresholds for each soil heavy metal are decided based on four-group $\mathrm{pH}$ intervals $(\leq 5.5,5.5-6.5,6.5-7.5$, and $>7.5$ ). Soil $\mathrm{pH}$ can significantly affect the presence and adsorption of heavy metals in soil. The risk screening values and risk intervention values are presented in Table 2. The classification criteria for pollution risk assessment of heavy metals is shown in Table 3.

\section{Contamination Assessment of Agricultural Products}

To quantify the heavy metal pollution level of agricultural products, the single-factor pollution index $\left(\mathrm{P}_{\mathrm{i}}\right)$ and the Nemerow pollution index $\left(\mathrm{P}_{\mathrm{N}}\right)$ were applied

Table 3. Classification criteria for pollution risk assessment of heavy metals in soil.

\begin{tabular}{|c|c|c|}
\hline Pollution risk level & Heavy metal content $(\mathrm{X})$ & Description of pollution risk level \\
\hline 1 & $\mathrm{X} \leq$ Risk screening value & $\begin{array}{c}\text { The risk of agricultural soil to the quality is relatively low } \\
\text { and can be ignored in general. }\end{array}$ \\
\hline 2 & $\begin{array}{c}\text { Risk screening value }<\mathrm{X} \leq \text { Risk intervention } \\
\text { value }\end{array}$ & There may be existed the potential soil contamination risk \\
\hline 3 & $\mathrm{X}>$ Risk intervention value & $\begin{array}{c}\text { The risk of agricultural soil is extremely high and reducing } \\
\text { pollution of soil to the quality and safety of agricultural } \\
\text { products is very difficult. }\end{array}$ \\
\hline
\end{tabular}


in this study. Single-factor assessment is usually expressed as a pollution index, which is defined as the following equations [27-30]:

$$
P_{i}=\frac{C_{i}}{S_{i}}
$$

...where $\mathrm{P}_{\mathrm{i}}$ is the pollution index of the heavy metal element $i, C_{i}$ is the detected concentration of heavy metal element $i$ in the investigated samples (agricultural products), and $\mathrm{S}_{i}$ is limit value of the target element $i$, which can be obtained according to relevant technical criteria. In this study, these criteria are the limit standards for national food pollutants (GB2762-2017).

The $\mathrm{P}_{\mathrm{i}}$ was classified as uncontaminated $\left(\mathrm{P}_{\mathrm{i}} \leq 1\right.$, Class I), slightly contaminated $\left(1<\mathrm{P}_{\mathrm{i}} \leq 2\right.$, Class II), moderately contaminated $\left(2<\mathrm{P}_{\mathrm{i}} \leq 3\right.$, Class III), and seriously contaminated $\left(\mathrm{P}_{\mathrm{i}}>3\right.$, Class IV).

Heavy metal pollution is a comprehensive compound pollution. Single-factor pollution assessment is difficult to use to evaluate the heavy metal pollution degree of various vegetable varieties. Therefore, the use of a multi-factor comprehensive index evaluation method can overcome the limitation of the single-factor index method and can highlight the effect of pollutants with heavy pollution. Nemerow pollution index is one of the most common measures for comprehensively assessing levels of pollution by heavy metals [31-32]. It is calculated by the following equation:

$$
P_{N}=\sqrt{\frac{P_{\max }^{2}+P_{a v e}^{2}}{2}}
$$

...where $\mathrm{P}_{\mathrm{N}}$ is the comprehensive pollution index and $\mathrm{P}_{\max }$ is the maximum value of the single pollution index of the heavy metal, which is described as follows: $\mathrm{P}_{\max }=\max \left\{\mathrm{P}_{1}, \cdots, \mathrm{P}_{\mathrm{n}}\right\}, \mathrm{P}_{\text {ave }}$ is the average value of the individual factor index, which can be calculated from the following equation:

$$
P_{\text {ave }}=\frac{1}{n} \sum_{i=1}^{n} P_{i}
$$

According to the integrated Nemerow pollution index, soil quality can be classified as safe $\left(\mathrm{P}_{\mathrm{N}} \leq 0.7\right.$, Class I), warning $\left(0.7<\mathrm{P}_{\mathrm{N}} \leq 1\right.$, Class II), light pollution $\left(1<\mathrm{P}_{\mathrm{N}} \leq 2\right.$, Class III), moderate pollution $\left(2<\mathrm{P}_{\mathrm{N}} \leq 3\right.$, Class IV), and heavy pollution $\left(\mathrm{P}_{\mathrm{N}}>3\right.$, Class $\left.\mathrm{V}\right)$.

\section{Health Risk Assessment}

Health risk assessment of urban topsoil is widely used to quantify both carcinogenic and non-carcinogenic risks to humans via three exposure pathways: ingestion, dermal contact and inhalation [18, 19].

The harm of environmental pollutants on the human body studied in this paper was mainly exposed by ingestion, which was used to assess the health risk of heavy metals through food consumption among adults and children. The methodology used in this research to calculate the exposure risks of heavy metals is based on the USEPA model [33-35]. The dose received through ingestion can be calculated using the following equation:

$$
A D D=\frac{C \times I R \times E D \times E F}{B W \times A T \times 365}
$$

...where ADD represents the average daily exposure dose of heavy metal $\left(\mathrm{mg} \cdot \mathrm{kg}^{-1} \cdot \mathrm{d}^{-1}\right), C$ represents the concentration of heavy metals in edible part of agricultural products $\left(\mathrm{mg} \cdot \mathrm{kg}^{-1}\right)$, IR represents daily vegetable consumption $\left(\mathrm{kg} \cdot \mathrm{d}^{-1}\right)$, ED represents exposure duration (a), EF represents exposure frequency $\left(\mathrm{d} \cdot \mathrm{a}^{-1}\right), \mathrm{BW}$ represents average body weight $(\mathrm{kg})$, and AT represents the average time period of exposure (a) mean life calculation.

The ADD of different heavy metals through various pathways was calculated according to the USEPA Health Risk Handbook [35] and the Technical Guidelines for Risk Assessment of Contaminated Sites (HJ25.3-2014).

In this research, non-carcinogenic and carcinogenic effects of heavy metals were assessed using the hazard quotient (HQ) and carcinogenic risk (CR) methods, respectively [28, 36-37]. HQ is calculated as the ratio of the ADD and a reference dose (RfD). The equation is as follows:

$$
H Q=\frac{A D D}{R \mathrm{f} D}
$$

...where HQ represents the hazard quotient of heavy metal and RfD represents the oral reference dose of heavy metal $\left(\mathrm{mg} \cdot \mathrm{kg}^{-1} \cdot \mathrm{d}^{-1}\right)$. The RfD value is the maximum daily dose of a metal from aspecific exposure pathway, for both adults and children, that is believed not to lead to an appreciable risk of deleterious effects to sensitive individuals during a lifetime.

If HQ value is $\leq 1$, the exposed population is unlikely to experience obvious adverse health effects. HQ value $>1$ shows that there is a chance that non-carcinogenic risk may occur [34- 35].

Carcinogenic risk is regarded as the probability of an individual developing any type of cancer due to exposure to carcinogenic hazards [4]. The carcinogenic risk of heavy metals through the inhalation pathway was estimated and calculated using the following equation [38].

$$
C R=A D D \times S F
$$

...where CR represents the carcinogenic risk and SF represents the carcinogenic slope factor $\left(\mathrm{kg} \cdot \mathrm{d}^{-1} \cdot \mathrm{mg}^{-1}\right)$.

The value of risk within the range of $1 \times 10^{-6}$ to $1 \times 10^{-4}$ is considered acceptable or tolerable, whereas if the value of risk is higher than $1 \times 10^{-4}$, the human body 
Table 4. Health risk parameters and values used.

\begin{tabular}{|c|c|c|c|c|}
\hline \multirow{2}{*}{ Parameters } & \multirow{2}{*}{ Unit } & \multicolumn{2}{|c|}{ Values used } & \multirow{2}{*}{$\begin{array}{c}\text { Sources } \\
\text { /References }\end{array}$} \\
\hline & & Adults & Children & \\
\hline BW & $\mathrm{kg}$ & 70 & 16 & [33-34] \\
\hline $\mathrm{ED}$ & a & 30 & 10 & {$[34]$} \\
\hline IR & $\mathrm{kg} \cdot \mathrm{d}^{-1}$ & 0.150 (corn); 0.269 (vegetable) & 0.100 (corn); 0.240 (vegetable) & {$[42-44]$} \\
\hline $\mathrm{EF}$ & $d \cdot a^{-1}$ & \multicolumn{2}{|c|}{365} & {$[33]$} \\
\hline AT(non-carcinogenic) & a & \multicolumn{2}{|c|}{70} & {$[33]$} \\
\hline AT(carcinogenic) & a & 30 & 10 & {$[34]$} \\
\hline RfD & $\mathrm{mg} \cdot \mathrm{kg}^{-1} \cdot \mathrm{d}^{-1}$ & \multicolumn{2}{|c|}{$0.001(\mathrm{Cd}) ; 0.04(\mathrm{Cu}) ; 1.5(\mathrm{Cr}) ; \quad 0.004(\mathrm{~Pb})$} & {$[45]$} \\
\hline $\mathrm{SF}$ & $\mathrm{mg} \cdot \mathrm{kg}^{-1} \cdot \mathrm{d}^{-1}$ & \multicolumn{2}{|c|}{$6.1(\mathrm{Cd}) ; \quad-(\mathrm{Cu}) ; 0.5(\mathrm{Cr}) ; 0.0085(\mathrm{~Pb})$} & {$[18,46]$} \\
\hline
\end{tabular}

would be affected by carcinogenic hazards [34, 3840]. According to the classification of carcinogen by the International Agency for Research on Cancer (IARC), $\mathrm{Cd}$ and $\mathrm{Cr}$ are identified as human carcinogens (Class I) while $\mathrm{Pb}$ is regarded as a probable carcinogen (Class II) [41]. The values used in Equations (4) to (6) are presented in Table 4.

\section{Statistical Analysis}

Results of this study were analyzed using SPSS Version 19.0 (SPSS Inc., Chicago, USA) to obtain a mean value, standard deviation, maximum and minimum. Descriptive analysis was performed for physico-chemical parameters and heavy metal contents in soil and agricultural product samples studied (in triplicates). All data used parametric statistical analysis (p-value $<0.05$ ). The office and Excel software 2016 plotted all figures and tables.

\section{Results and Discussion}

\section{Descriptive Statistical Analysis of Heavy Metal Concentrations}

\section{Concentrations of Heavy Metal in Soils}

The OM contents were in the range of $3.15-8.80 \%$ with a mean of $5.10 \%$, presenting a large variation. Low OM content in soils around tailing dumps is not unexpected because the environment is devoid of plant nutrients and the acidic nature of tailings would hinder vegetation growth, limiting the amount of organic matter in the soils. The soil $\mathrm{pH}$ ranges from 4.6 to 6.5 , with an average value of 5.7, suggesting slightly acidic conditions. This may be associated with the oxidation of sulfides in the tailings to release a certain amount of acid that entered into the pore water, and then into the downstream fields $[6,12]$. The acidic nature of the soils would increase the mobility of potentially toxic heavy metals, increasing their potential to cause harm to the environment. The statistical analysis of the concentration of heavy metals in soils is shown in Table 5 .

In this table, the average values of the four heavy metals of soil samples from the study area were significantly higher than the soil background value in Henan Province [47], illustrating the influence of anthropogenic mining activities. In comparison with the values of $\mathrm{Cd}, \mathrm{Cu}, \mathrm{Cr}$ and $\mathrm{Pb}$ in the Henan background soil, the mean concentrations of heavy metals in soils exceeded the local background levels by $70.33,3.65,1.17$ and 3.97 times, respectively. If the Chinese agricultural soil environmental quality control criteria (GB156182018) is used as a reference, the maximum concentration levels of four types of heavy metal all exceed the risk screening values, which indicated that there existed a potential soil contamination risk in the studied area. To be specific, the maximum concentrations of $\mathrm{Cd}, \mathrm{Cu}$, $\mathrm{Cr}$ and $\mathrm{Pb}\left(\mathrm{mg} \cdot \mathrm{kg}^{-1}\right)$ in soil were 9.57, 168.24, 175.31 and 402.55, respectively, and exceeded the risk screening values by $31.90,3.36,1.17$ and 4.47 times, respectively. In addition, the average contents of $\mathrm{Cd}$ and $\mathrm{Cu}$ in soils were 14.07- and 1.46-fold of the risk-screening values, respectively. However, the mean content of $\mathrm{Cd}$ in soils was not only higher than risk screening value, but also exceeded the risk intervention value issued by the Chinese agricultural soil environmental quality control criteria, suggesting a comparatively higher degree of contamination for $\mathrm{Cd}$ in soils in this region.

The coefficient of variation $(\mathrm{CV})$ reflects the degree of variability within heavy metal concentrations in soils. According to the analysis using $\mathrm{CV}$, we have $\mathrm{CV}$ values for $\mathrm{Cd}, \mathrm{Cu}, \mathrm{Cr}$ and $\mathrm{Pb}$ as 59.86\%, 64.04\%, 59.87\% and $97.06 \%$, respectively. These values show great variation due to exceeding $50 \%$, which indicate that the contents of heavy metals are obviously disturbed - especially metal $\mathrm{Pb}$. This result suggests that considerable variability exists in the heavy metal data and that the spatial distributions of heavy metals in this area are not homogeneous, which is probably caused by human activities. The difference of contents in study areas may be caused by topography, the development degree of the 
Table 5. Heavy metal contents of soils in the study area $\left(\mathrm{mg} \cdot \mathrm{kg}^{-1}\right)$.

\begin{tabular}{|c|c|c|c|c|c|c|c|c|}
\hline \multirow{2}{*}{ Element } & \multicolumn{3}{|c|}{ Study area $(\mathrm{n}=40)$} & Coefficient of \\
& variation/\% & $\begin{array}{c}\text { Background } \\
\text { values of Henan }\end{array}$ & $\begin{array}{c}\text { Risk screening } \\
\text { values }^{\mathrm{b}}\end{array}$ & $\begin{array}{c}\text { Risk intervention } \\
\text { values }^{\mathrm{b}}\end{array}$ & Proportion $^{\mathrm{c}}$ \\
\hline $\mathrm{Cd}$ & 9.57 & 0.35 & $4.22 \pm 2.51$ & 59.86 & 0.06 & 0.3 & 2.0 & 70.33 \\
\hline $\mathrm{Cu}$ & 168.24 & 18.16 & $73.02 \pm 46.85$ & 64.04 & 20.00 & 50 & - & 3.65 \\
\hline $\mathrm{Cr}$ & 175.31 & 14.97 & $73.90 \pm 44.26$ & 59.87 & 63.20 & 150 & 850 & 1.17 \\
\hline $\mathrm{Pb}$ & 402.55 & 2.91 & $88.63 \pm 85.99$ & 97.06 & 22.30 & 90 & 500 & 3.97 \\
\hline
\end{tabular}

Notes: $\mathrm{n}=$ Number of sampling points, Max. $=$ Maximum value, Min. $=$ Minimum value, $\mathrm{SD}=$ Standard deviation.

${ }^{a}$ Background Values of Soil Environment in Henan Province [47]

${ }^{\mathrm{b}}$ Chinese Agricultural Soil Environmental Quality Control Criteria (GB15618-2018)

${ }^{\mathrm{c}}$ Proportion $=$ Measured value/ The background value of Henan Province

sampling point, the distance from the pollution source and other factors.

According to the significant different test, the pollution degree showed a characteristics order of $\mathrm{Cd}>\mathrm{Pb}>\mathrm{Cu}>\mathrm{Cr}$. In summary, these results reflect the long-term mining and smelting activities that have led to significant accumulations of $\mathrm{Cd}$ in topsoil. Based on this analysis, $\mathrm{Cd}$ was the primary pollutant in comparison to other metal elements investigated in the studied area, followed sequentially by $\mathrm{Pb}$ and $\mathrm{Cu}$. On the basis of field investigation and data analysis, the farmland area was mainly affected by the surrounding tailings reservoir. The wastewater and waste residue produced by the many surrounding tailings reservoirs that are being used and closed for many years were transported into the water and soil through migration and release. After years of accumulation, they caused serious pollution to the surrounding soil.

\section{Concentraions of Heavy Metal in Agricultural Products}

The contents of heavy metals in edible parts of agricultural products were determined and the relevant statistical values are shown in Table 6. The maximum allowable concentration standards for food in China (GB2762-2017) were also shown in Table 4. The standard for $\mathrm{Cu}$ in agricultural products was phased out in 2011 and the new standard has not yet been set. In this study, the old criterion of tolerance limit of copper in foods is applied to the regulated contamination level of $\mathrm{Cu}\left(10 \mathrm{mg} \cdot \mathrm{kg}^{-1}\right)$ in agricultural products (GB15199-

Table 6. Concentrations of heavy metals in agricultural products and maximum permissible levels set in China $\left(\mathrm{mg}^{\circ} \mathrm{kg}^{-1}\right)$.

\begin{tabular}{|c|c|c|c|c|c|}
\hline Types of agricultural products & Values contrast & $\mathrm{Cd}$ & $\mathrm{Cu}$ & $\mathrm{Cr}$ & $\mathrm{Pb}$ \\
\hline \multirow{5}{*}{$\begin{array}{l}\text { Leafy vegetables } \\
\qquad \mathrm{n}=25\end{array}$} & Range & $0.21-0.66$ & $0.60-6.60$ & $0.11-0.93$ & $0.23-0.95$ \\
\hline & Mean \pm SD & $0.47 \pm 0.13$ & $3.11 \pm 1.87$ & $0.51 \pm 0.26$ & $0.60 \pm 0.16$ \\
\hline & $\mathrm{CV} / \%$ & 27.4 & 60.3 & 50.7 & 26.7 \\
\hline & Permissible levels & 0.2 & 10 & 0.5 & 0.3 \\
\hline & Excessive Rate/\% & 100 & 0 & 25.5 & 96.7 \\
\hline \multirow{5}{*}{$\begin{array}{l}\text { Rhizomatous vegetables } \\
\qquad \mathrm{n}=12\end{array}$} & Range & $0.14-0.69$ & $0.10-4.95$ & $0.11-0.86$ & $0.12-0.79$ \\
\hline & Mean \pm SD & $0.36 \pm 0.15$ & $2.62 \pm 1.59$ & $0.33 \pm 0.25$ & $0.48 \pm 0.18$ \\
\hline & $\mathrm{CV} / \%$ & 42.1 & 60.8 & 77.4 & 38.1 \\
\hline & Permissible levels & 0.1 & 10 & 0.5 & 0.2 \\
\hline & Excessive Rate $/ \%$ & 100 & 0 & 18.4 & 91.3 \\
\hline \multirow{5}{*}{$\begin{array}{l}\text { Corns } \\
\mathrm{n}=8\end{array}$} & Range & $0.17-0.68$ & $1.02-9.71$ & $0.21-1.40$ & $0.13-0.77$ \\
\hline & Mean \pm SD & $0.44 \pm 0.17$ & $5.15 \pm 2.79$ & $0.60 \pm 0.38$ & $0.42 \pm 0.13$ \\
\hline & $\mathrm{CV} / \%$ & 37.8 & 54.3 & 63.7 & 32.1 \\
\hline & Permissible levels & 0.1 & 10 & 1.0 & 0.2 \\
\hline & Excessive Rate/\% & 100 & 0 & 10.5 & 64.3 \\
\hline
\end{tabular}

Notes: $\mathrm{SD}=$ Standard deviation, $\mathrm{CV}=$ Coefficient of variation. 
Table 7. Pearson correlation coefficients between heavy metal contents in soils $\left(\mathrm{mg} \cdot \mathrm{kg}^{-1}\right)$ and agricultural products $\left(\mathrm{mg} \cdot \mathrm{kg}^{-1}\right)$.

\begin{tabular}{|c|c|c|c|c|c|c|c|c|c|}
\hline Soil & $\mathrm{Cd}$ & $\mathrm{Cu}$ & $\mathrm{Cr}$ & $\mathrm{Pb}$ & $\mathrm{A} . \mathrm{P}$ & $\mathrm{Cd}$ & $\mathrm{Cu}$ & $\mathrm{Cr}$ & $\mathrm{Pb}$ \\
\hline $\mathrm{Cd}$ & 1 & & & & $\mathrm{Cd}$ & 1 & & & \\
\hline $\mathrm{Cu}$ & $0.379^{*}$ & 1 & & & $\mathrm{Cu}$ & $0.427^{*}$ & 1 & & \\
\hline $\mathrm{Cr}$ & 0.268 & $0.674^{* *}$ & 1 & & $\mathrm{Cr}$ & 0.652 & $0.525^{*}$ & 1 & \\
\hline $\mathrm{Pb}$ & $0.790^{* *}$ & 0.288 & 0.185 & 1 & $\mathrm{~Pb}$ & $0.271^{*}$ & $0.363^{*}$ & 0.252 & 1 \\
\hline
\end{tabular}

Notes: A.P. is the abbreviation of agricultural products

* Correlation is significant at the 0.05 level (two-tailed)

** Correlation is significant at the 0.01 level (two-tailed)

94). The average concentrations of $\mathrm{Cd}, \mathrm{Cu}, \mathrm{Cr}$ and $\mathrm{Pb}$ in the edible part of leafy vegetables were higher than those of rhizome vegetables, which were consistent with the results of the studies of Yang J. et al. [20] and Li X.Y. et al. [48]. It shows that leafy vegetable are more likely to accumulate metals than other agricultural products. The concentration of $\mathrm{Cd}$ in all agricultural products was higher than the permissible level, and the excessive rate reached $100 \%$. The results were in accordance with the most serious pollution of $\mathrm{Cd}$ in farmland soil. In terms of the average values, the order of concentration for $\mathrm{Pb}$ was found to be leafy vegetables $>$ rhizomatous vegetables $>$ corn, and the excessive rates reached $96.7 \%, 91.3 \%$ and $64.3 \%$, respectively. Yang J. et al. reported that more than $50 \%$ of the $\mathrm{Pb}$ in the atmosphere could be absorbed directly from the leaves of vegetables [20], and the heavy metals carried by the atmospheric sedimentation particles were easily adsorbed and enriched on the surface of the leaves [48]. Hence, our study suggested that the accumulations of $\mathrm{Pb}$ in plants might be mainly from the direct foliar uptake of atmospheric $\mathrm{Pb}$ related to mining-smelting activities. The concentrations of $\mathrm{Cd}$ and $\mathrm{Pb}$ in the study area were higher than the permissible level, indicating that they might cause a potential risk for humans. The order of concentration for $\mathrm{Cu}$ and $\mathrm{Cr}$ was found to be corn>leafy vegetables $>$ rhizomatous vegetables. The trace elements necessary for the plant $(\mathrm{Cu})$ is abundant in all type of vegetables. According to the standard GB15199-94, the content of $\mathrm{Cu}$ in agricultural products of this study is substantially lower than the permissible level $\left(10 \mathrm{mg} \cdot \mathrm{kg}^{-1}\right.$ for $\left.\mathrm{Cu}\right)$. The plants not only control the absorption of $\mathrm{Cu}$ through the regulation mechanism, but also grow normally in an environment where the content of $\mathrm{Cu}$ in the soil exceeds the standard.

\section{Correlation Analysis of Heavy Metal in Soils and Agricultural Products}

Correlation analysis is usually used to provide important information on the sources and pathways of the metals. In this research, Pearson's correlation coefficient was applied to determine the inter-elemental relationships of heavy metals in soil and agricultural product samples, which are shown in Table 7 .
We found that some pairs of heavy metals had very highly significant positive correlations in soils like $\mathrm{Cd}-\mathrm{Pb}(\mathrm{r}=0.790)$ and $\mathrm{Cr}-\mathrm{Cu}(\mathrm{r}=0.674)$ at the $\mathrm{p}<0.01$ significance level. Moderated positive correlation was also detected between $\mathrm{Cu}$ and $\mathrm{Cd}$, with $\mathrm{r}=0.379$ at $\mathrm{p}<0.05$ level. A clear positive correlation existed between them, suggesting that these metals are derived from the same source, and especially have a stronger correlation with mining and smelting activities [48-51]. Previous studies [13, 49, 50] have stated that two pathways may contribute to distributing heavy metals throughout the mining area. One way is that heavy metals in the slags or tailings can be dissolved and transported to the mine's surrounding environment by means of acidic drainage [13]. Atmospheric deposition may be another important factor influencing the contents of heavy metal in soil [49]. Once entering the soil, the heavy metals will have a long-term retention by complexation or adsorption reaction with organic substances in soils [52]. Similarly, significant correlation was found in agricultural products, $\mathrm{Cd}-\mathrm{Pb}(\mathrm{r}=0.271)$, $\mathrm{Cr}-\mathrm{Cu}(\mathrm{r}=0.525), \mathrm{Cd}-\mathrm{Cu}(\mathrm{r}=0.427)$ and $\mathrm{Pb}-\mathrm{Cu}$ $(\mathrm{r}=0.363)$ at the $\mathrm{p}<0.05$ level, which were comparatively weaker than that in soils. This implies that these metals originate from the same polluting source or present multiple contamination to different degrees [53]. The significant correlation coefficients between heavy metals in soils and agricultural products assume that the source of heavy metal pollution in mining areas was anthropogenic (mining and smelting activities).

\section{Assessing Heavy Metal Pollution in Agricultural Products}

The pollution levels of agricultural products are assessed by the single-factor and comprehensive pollution indices. The results are shown in Table 8. The contamination levels of $\mathrm{Cu}$ and $\mathrm{Cr}$ in the agricultural products were classified to Class I (uncontaminated), while the levels of $\mathrm{Cd}$ and $\mathrm{Pb}$ in the agricultural products reached Classes II-IV (slightly to seriously contaminated). This showed that agricultural products were not polluted by $\mathrm{Cu}$ and $\mathrm{Cr}$, though they are seriously polluted by $\mathrm{Pb}$ and $\mathrm{Cd}$. The single-factor index of $\mathrm{Cd}$ for rhizomatous vegetables and corn were more than 3, which belonged to serious pollution, and which 
Table 8. Result of single-factor and comprehensive pollution index assessment of agricultural products.

\begin{tabular}{|c|c|c|c|c|c|c|c|c|c|c|}
\hline \multirow{2}{*}{ Sample } & \multicolumn{2}{|c|}{$\mathrm{Cd}$} & \multicolumn{2}{|c|}{$\mathrm{Cu}$} & \multicolumn{2}{|c|}{$\mathrm{Cr}$} & \multicolumn{2}{|c|}{$\mathrm{Pb}$} & \multirow{2}{*}{$P_{N}$} & \multirow{2}{*}{ Class } \\
\hline & $P_{i}$ & Class & $P_{i}$ & Class & $P_{i}$ & Class & $P_{i}$ & Class & & \\
\hline White cabbage & 2.33 & III & 0.38 & I & 0.99 & I & 2.11 & III & 1.94 & III \\
\hline Cauliflower & 2.13 & III & 0.27 & I & 0.84 & I & 1.82 & II & 1.75 & III \\
\hline Cabbage & 2.40 & III & 0.16 & I & 1.15 & II & 1.87 & II & 1.96 & III \\
\hline Scallion & 2.58 & III & 0.38 & I & 1.14 & II & 2.18 & III & 2.14 & IV \\
\hline Carrot & 3.46 & IV & 0.34 & I & 0.73 & V & 2.47 & III & 2.74 & IV \\
\hline White radish & 3.70 & IV & 0.18 & I & 0.72 & V & 2.46 & III & 2.90 & IV \\
\hline Potato & 3.97 & IV & 0.29 & I & 0.41 & I & 2.10 & III & 3.05 & $\mathrm{~V}$ \\
\hline Corn & 4.48 & IV & 0.52 & I & 0.61 & I & 2.13 & III & 3.45 & V \\
\hline Leafy vegetables & 2.36 & III & 0.31 & I & 1.03 & II & 2.01 & III & 1.95 & III \\
\hline Rhizomatous vegetables & 3.67 & IV & 0.26 & I & 0.66 & I & 2.38 & III & 2.87 & IV \\
\hline
\end{tabular}

especially in corn reached 4.48. Except for cauliflower and broccoli, the pollution index of $\mathrm{Pb}$ for vegetables and corn were all greater than 2 , reaching moderate pollution.

Based on the comprehensive pollution index $\left(\mathrm{P}_{\mathrm{N}}\right)$, the pollution level rank was corn $>$ potato $>$ white radish $>$ carrot $>$ scallion $>$ cabbage $>$ white cabbage $>$ cauliflower. In this sequence, corn and potato were in Class V (heavy pollution); white radish, carrot and scallion were in Class IV (moderate pollution); and cabbage, white cabbage and cauliflower were in Class III (light pollution). In terms of vegetable categories, the order of $\mathrm{P}_{\mathrm{N}}$ was found to be rhizomatous vegetables>leaf vegetables. The results show that rhizomatous vegetables were more likely to accumulate heavy metals than leaf vegetables.

The individual index values of risk assessment of heavy metals indicate that $\mathrm{Cd}$ is the main contributor to ecological risk. This is because its assessment results are far greater than those of the other heavy metals. The study area is at a strong level of potential risk, which is consistent with the assessment results listed in Tables 5 and 6 , which indicate that the entire study area has reached a strong potential risk level. Luanchuan is an important industrial and mining county in Henan Province; therefore, the study area is inevitably affected by mining activities in Luanchuan, which results in serious Cd pollution.

\section{Health Risk Assessment of Agricultural Products}

The non-carcinogenic ADD, carcinogenic ADD, HQ and CR values of heavy metal intake through agricultural products by adults and children around the tailings reservoir area were calculated by the health risk assessment model. The health risks of agricultural products are shown in Table 9. It was found that the order of both non-carcinogenic ADD and carcinogenic ADD was leaf vegetables $>$ corn $>$ rhizomatous vegetables.
The non-carcinogenic ADD of children was higher than that of adults; however, the carcinogenic ADD of adults caused by heavy metals ingestion through leaf vegetables and corn was higher than that of children. The order of non-carcinogenic ADD and carcinogenic ADD through agricultural products for heavy metals was found to be $\mathrm{Cu}>\mathrm{Pb}>\mathrm{Cr}>\mathrm{Cd}$.

From the non-carcinogenic risk, the results showed that the $\mathrm{HQ}$ values of $\mathrm{Cd}$ and $\mathrm{Pb}$ in leaf vegetables for both children and adults exceed 1, suggesting high health risks by consuming the contaminated agricultural products. As a comparison, the other HQ values in agricultural products were less than 1, which were regarded as safe both for children and adults. For adults and children, the order of non-carcinogenic risk caused by heavy metals ingestion through agricultural products was $\mathrm{Cd}>\mathrm{Pb}>\mathrm{Cu}>\mathrm{Cr}$. It is clear that $\mathrm{Cd}$ and $\mathrm{Pb}$ are the most significant heavy metal pollution caused by mining and smelting activities, which is consistent with the research of Barkett M. O. et al. [51]. The hazards of $\mathrm{Cd}$ and $\mathrm{Pb}$ are considered to be potential carcinogens and pathogens of many diseases - especially cardiovascular, kidney, blood, nerve and bone diseases. According to literature [48-50], the local residents in mining area were excessively exposed to $\mathrm{Cd}$ and $\mathrm{Pb}$ through agricultural product consumption alone. Comparative analysis of the non-carcinogenic risk for adults and children, it was found that the noncarcinogenic risk of leaf vegetables was the highest of all kinds of agricultural products, and the HQ values of children in the agricultural products were higher than that of adults. The results indicated that the health risk of heavy metal through vegetable intake on children was higher than that of adults. Much research [5456] has indicated that children were typically more susceptible to a given dose of toxins than adults in the case of heavy metal exposure through diet, which were likely to inadvertently ingest significant quantities of heavy metals in agricultural products. 
Table 9. Non-carcinogenic and carcinogenic risk values of heavy metal for local resident via agricultural product consumption.

\begin{tabular}{|c|c|c|c|c|c|c|c|c|c|}
\hline \multirow{3}{*}{$\begin{array}{c}\text { Types of agricultural } \\
\text { products }\end{array}$} & \multirow{3}{*}{$\begin{array}{l}\text { Heavy } \\
\text { metal }\end{array}$} & \multicolumn{4}{|c|}{ Non-carcinogenic risk } & \multicolumn{4}{|c|}{ Carcinogenci risk } \\
\hline & & \multicolumn{2}{|c|}{$\mathrm{ADD} /\left(\mathrm{mg} \cdot \mathrm{kg}^{-1} \cdot \mathrm{d}^{-1}\right)$} & \multicolumn{2}{|c|}{ HQ } & \multicolumn{2}{|c|}{$\mathrm{ADD} /\left(\mathrm{mg} \cdot \mathrm{kg}^{-1} \cdot \mathrm{d}^{-1}\right)$} & \multicolumn{2}{|c|}{$\mathrm{CR}$} \\
\hline & & Adults & Children & Adults & Children & Adults & Children & Adults & Children \\
\hline \multirow{4}{*}{$\begin{array}{c}\text { Leafy } \\
\text { vegetables }\end{array}$} & $\mathrm{Cd}$ & $1.7 \times 10^{-3}$ & $2.6 \times 10^{-3}$ & 1.76 & 2.68 & $7.5 \times 10^{-4}$ & $3.8 \times 10^{-4}$ & $4.6 \times 10^{-3}$ & $2.3 \times 10^{-3}$ \\
\hline & $\mathrm{Cu}$ & $2.2 \times 10^{-2}$ & $3.4 \times 10^{-2}$ & 0.57 & 0.87 & $9.7 \times 10^{-3}$ & $4.9 \times 10^{-3}$ & - & - \\
\hline & $\mathrm{Cr}$ & $2.6 \times 10^{-3}$ & $4.1 \times 10^{-3}$ & $1.7 \times 10^{-3}$ & $2.7 \times 10^{-3}$ & $1.1 \times 10^{-3}$ & $5.8 \times 10^{-4}$ & $5.7 \times 10^{-4}$ & $2.9 \times 10^{-4}$ \\
\hline & $\mathrm{Pb}$ & $4.7 \times 10^{-3}$ & $7.2 \times 10^{-3}$ & 1.18 & 1.81 & $2.1 \times 10^{-3}$ & $1.1 \times 10^{-3}$ & $1.7 \times 10^{-5}$ & $8.8 \times 10^{-6}$ \\
\hline \multirow{4}{*}{$\begin{array}{l}\text { Rhizomatous } \\
\text { vegetables }\end{array}$} & $\mathrm{Cd}$ & $6.0 \times 10^{-4}$ & $7.9 \times 10^{-4}$ & 0.60 & 0.79 & $2.1 \times 10^{-5}$ & $9.1 \times 10^{-5}$ & $1.3 \times 10^{-4}$ & $5.5 \times 10^{-4}$ \\
\hline & $\mathrm{Cu}$ & $4.3 \times 10^{-3}$ & $8.4 \times 10^{-3}$ & 0.11 & 0.21 & $2.9 \times 10^{-4}$ & $1.2 \times 10^{-3}$ & - & - \\
\hline & $\mathrm{Cr}$ & $7.1 \times 10^{-5}$ & $8.8 \times 10^{-4}$ & $4.7 \times 10^{-5}$ & $5.9 \times 10^{-4}$ & $3.1 \times 10^{-5}$ & $1.2 \times 10^{-4}$ & $1.5 \times 10^{-5}$ & $6.3 \times 10^{-5}$ \\
\hline & $\mathrm{Pb}$ & $7.9 \times 10^{-4}$ & $1.0 \times 10^{-3}$ & 0.20 & 0.26 & $3.8 \times 10^{-5}$ & $1.6 \times 10^{-4}$ & $3.3 \times 10^{-7}$ & $1.4 \times 10^{-6}$ \\
\hline \multirow{4}{*}{ Corns } & $\mathrm{Cd}$ & $2.5 \times 10^{-4}$ & $7.3 \times 10^{-4}$ & 0.25 & 0.73 & $1.1 \times 10^{-4}$ & $1.1 \times 10^{-4}$ & $6.5 \times 10^{-4}$ & $6.3 \times 10^{-4}$ \\
\hline & $\mathrm{Cu}$ & $5.9 \times 10^{-3}$ & $1.7 \times 10^{-2}$ & 0.15 & 0.43 & $2.5 \times 10^{-3}$ & $2.4 \times 10^{-3}$ & - & - \\
\hline & $\mathrm{Cr}$ & $8.6 \times 10^{-4}$ & $2.5 \times 10^{-3}$ & $5.7 \times 10^{-4}$ & $1.6 \times 10^{-3}$ & $3.7 \times 10^{-4}$ & $3.6 \times 10^{-4}$ & $1.8 \times 10^{-4}$ & $1.8 \times 10^{-4}$ \\
\hline & $\mathrm{Pb}$ & $3.9 \times 10^{-4}$ & $3.7 \times 10^{-4}$ & 0.10 & 0.09 & $3.6 \times 10^{-4}$ & $3.6 \times 10^{-4}$ & $3.1 \times 10^{-6}$ & $3.1 \times 10^{-6}$ \\
\hline
\end{tabular}

The carcinogenic risks were only estimated for $\mathrm{Cd}$, $\mathrm{Cr}$ and $\mathrm{Pb}$ due to the lack of carcinogenic SF for $\mathrm{Cu}$. Comparatively speaking, the carcinogenic risks for different agricultural products varied slightly, generally in the order of $\mathrm{Cd}>\mathrm{Cr}>\mathrm{Pb}$. For adults and children, the $\mathrm{CR}$ values of $\mathrm{Cd}$ exceed $1 \times 10^{-4}$ through consumption of agricultural products; meanwhile, the $\mathrm{CR}$ values of $\mathrm{Cr}$ exceed $1 \times 10^{-4}$ through consumption of leaf vegetables and corn. Comparative analysis of the carcinogenic risks for adults and children found that the $\mathrm{CR}$ values for children in the leafy vegetables were higher than for adults, and were less than for adults in other agricultural products. The results indicated that the carcinogenic risk caused by heavy metals ingestion through leafy vegetables was the highest of all agricultural products, whether adults or children - suggesting high risk levels.

Therefore, the results suggest that agricultural product consumption should take into account the noncarcinogenic effects of $\mathrm{Cd}$ and $\mathrm{Pb}$ and the carcinogenic effects of $\mathrm{Cd}$ and $\mathrm{Cr}$, which indicates that there is a high health risk for the local residents to eat vegetables grown in farmland around a tailings reservoir. We suggest planting vegetables away from the surrounding areas of a tailing reservoir. Local residents can also reduce vegetable consumption and consume more grains in order to decrease the non-carcinogenic and carcinogenic risks.

\section{Conclusions}

The heavy metal contamination of farmland soil and agricultural products around the tailings area in Henan Province of China was investigated in this research.
The heavy metal contents of soil in the study area were higher than the soil background value of Henan Province. Compared with the risk screening values of the national standard (GB15618-2018), the pollution degree of heavy metals followed the decreasing order of $\mathrm{Cd}>\mathrm{Cu}>\mathrm{Pb}>\mathrm{Cr}$. The results showed that $\mathrm{Cd}$ was the primary heavy metal contaminant in the farmland soil near the tailings area.

In terms of the average values, the order of concentration for heavy metals was found to be leafy vegetables $>$ rhizomatous vegetables $>$ corn. Compared to the limit value of pollutants in food (GB2762-2017), the agricultural products from the study area were seriously polluted by $\mathrm{Cd}$, and the excessive rates of $\mathrm{Cd}$ in all agricultural products were $100 \%$. The evaluation of heavy metal pollution in agricultural products showed that the primary heavy metal contaminants are $\mathrm{Cd}$ and $\mathrm{Pb}$. According to $\mathrm{P}_{\mathrm{N}}$, the contamination level in the agricultural products decreased in the following order: corn, potato, white radish, carrot, scallion, cabbage, white cabbage, cauliflower.

From the Non-carcinogenic risk, the HQ values of $\mathrm{Cd}$ and $\mathrm{Pb}$ in leafy vegetables for both children and adults exceed 1, which may bring health risks to local residents. This indicated that $\mathrm{Cd}$ and $\mathrm{Pb}$ were the main factors among the four elements of leafy vegetables. From the carcinogenic risk, the $\mathrm{CR}$ values of $\mathrm{Cd}$ exceed $1 \times 10^{-4}$ through the consumption of agricultural products, which indicates that there is a high health risk for the local residents. Comparatively speaking, the health risks for different agricultural products varied slightly, with children generally higher than adults. In future research, the sources and transformation of heavy metal pollution needs to be studied in order to provide a basis 
for health risk management from the perspective of a mining area.

\section{Acknowledgements}

This research was funded by the National Natural Science Foundation of China (No. 51008118) and the Key Scientific Research Project of Henan Higher Education Institutions (No. 18B610001). We would like to express our gratitude to Zhang Jun and Wang Kai for laboratory assistance. The authors also acknowledge the anonymous referees for their constructive comments.

\section{Conflict of Interest}

The authors declare no conflict of interest.

\section{References}

1. HUANG S.H., YUAN C.Y., LI Q., YANG Y., TANG C.J., OUYANG K., WANG B. Distribution and Risk Assessment of Heavy Metals in Soils from a Typical PbZn Mining Area. Polish Journal of Environmental Studies, 26 (3), 1105, 2017.

2. LIN W.J., XIAO T.F., ZHOU W.C., NING Z.P. Pb, Zn, and $\mathrm{Cd}$ Distribution and Migration at a Historical Zinc Smelting Site. Polish Journal of Environmental Studies, 24 (2), 575, 2015.

3. LI X., YANG H., ZHANG C., ZENG G., LIU Y., XU W., WU Y., LAN S. Spatial distribution and transport characteristics of heavy metals around an antimony mine area in central China. Chemosphere, 170, 17, 2017.

4. LI Z.Y., MA Z.W., VAN DER KUIJP T.J., YUAN Z.W., HUANG L. A review of soil heavy metal pollution from mines in China: Pollution and health risk assessment. Science of the Total Environment, 468, 843, 2014.

5. IGWE O., UNA C.O., ABU E., ADEPEHIN E.J. Environmental risk assessment of lead-zinc mining: a case study of Adudu metallogenic province, middle Benue Trough, Nigeria. Environmental Monitoring and Assessment, 189 (10), 2017.

6. YE M., YAN P., SUN S., HAN D., XIAO X., ZHENG L., HUANG S., CHEN Y., ZHUANG S. Bioleaching combined brine leaching of heavy metals from leadzinc mine tailings: Transformations during the leaching process. Chemosphere, 168, 1115, 2017.

7. 7. M.L., AMBROSI J.P. Pollution and ecological risk assessment of heavy metals in the soil-plant system and the sediment-water column around a former $\mathrm{Pb} / \mathrm{Zn}$-mining area in NE Morocco. Ecotoxicology and Environmental Safety, 144, 464, 2017.

8. LEE M., PAIK I.S., KIM I., KANG H., LEE S. Remediation of heavy metal contaminated groundwater originated from abandoned mine using lime and calcium carbonate. Journal of Hazardous materials, 144 (1-2), 208, 2007.

9. SHEN F., LIAO R.M., ALI A., MAHAR A., GUO D., LI R.H., SUN X.N., AWASTHI M.K., WANG Q., ZHANG Z.Q. Spatial distribution and risk assessment of heavy metals in soil near a $\mathrm{Pb} / \mathrm{Zn}$ smelter in Feng County,
China. Ecotoxicology and Environmental Safety, 139, 254, 2017.

10. KIM C.S., ANTHONY T.L., GOLDSTEIN D., RYTUBA J.J. Windborne transport and surface enrichment of arsenic in semi-arid mining regions: Examples from the Mojave Desert, California. Aeolian Research, 14, 85, 2014.

11. LIN W.J., XIAO T.F., ZHOU W.C., NING Z.P. Pb, Zn, and $\mathrm{Cd}$ Distribution and Migration at a Historical Zinc Smelting Site. Polish Journal of Environmental Studies, 24 (2), 575, 2015.

12. LIU B., PENG T., SUN H. Leaching behavior of U, Mn, $\mathrm{Sr}$, and $\mathrm{Pb}$ from different particle-size fractions of uranium mill tailings. Environmental Science and Pollution Research, 24 (18), 15804, 2017.

13. RODRIGUEZ L., RUIZ E., ALONSO-AZCARATE J., RINCON J. Heavy metal distribution and chemical speciation in tailings and soils around a $\mathrm{Pb}-\mathrm{Zn}$ mine in Spain. Journal of Environmental Management, 90 (2), 1106, 2009.

14. SZOLNOKI Z., FARSANG A., PUSKAS I. Cumulative impacts of human activities on urban garden soils: Origin and accumulation of metals. Environmental Pollution, 177, 106, 2013.

15. ZHUANG P., LI Z.A., ZOU B., XIA H.P., WANG G. Heavy Metal Contamination in Soil and Soybean near the Dabaoshan Mine, South China. Pedosphere, 23 (3), 298, 2013.

16. MASEKI J., ANNEGARN H.J., SPIERS G. Health risk posed by enriched heavy metals (As, $\mathrm{Cd}$, and $\mathrm{Cr}$ ) in airborne particles from Witwatersrand gold tailings. Journal of the Southern African Institute of Mining and Metallurgy, 117 (7), 663, 2017.

17. OWSIANIAK M., HOLM P.E., FANTKE P., CHRISTIANSEN K.S., BORGGAARD O.K., HAUSCHILD M.Z. Assessing comparative terrestrial ecotoxicity of $\mathrm{Cd}, \mathrm{Co}, \mathrm{Cu}, \mathrm{Ni}, \mathrm{Pb}$, and $\mathrm{Zn}$ : The influence of aging and emission source. Environmental Pollution, 206, 400, 2015.

18. XIAO R., WANG S., LI R.H., WANG J.J., ZHANG Z.Q. Soil heavy metal contamination and health risks associated with artisanal gold mining in Tongguan, Shaanxi, China. Ecotoxicology and Environmental Safety, 141, 17, 2017.

19. LIU X.M., SONG Q.J., TANG Y., LI W.L., XU J.M., WU J.J., WANG F., BROOKES P.C. Human health risk assessment of heavy metals in soil-vegetable system: A multi-medium analysis. Science of the Total Environment, 463, 530, 2013.

20. YANG J., LV F., ZHOU J., SONG Y., LI F. Health Risk Assessment of Vegetables Grown on the Contaminated Soils in Daye City of Hubei Province, China. Sustainability, 9 (11), 2017.

21. DURUIBE J.O., OGWUEGBU M.O.C., EGWURUGWU J.N. Heavy metal pollution and human biotoxic effects. International Journal of the Physical Sciences, 2 (5), 112, 2007.

22. LEI K., GIUBILATO E., CRITTO A., PAN H.Y., LIN C.Y. Contamination and human health risk of lead in soils around lead/zinc smelting areas in China. Environmental Science and Pollution Research, 23 (13), 13128, 2016.

23. LI P.Z., LIN C.Y., CHENG H.G., DUAN X.L., LEI K. Contamination and health risks of soil heavy metals around a lead/zinc smelter in southwestern China. Ecotoxicology and Environmental Safety, 113, 391, 2015.

24. WU Q.H., LEUNG J.Y.S., GENG X.H., CHEN S.J., HUANG X.X., LI H.Y., HUANG Z.Y., ZHU L.B., CHEN J.H., LU Y.Y. Heavy metal contamination of soil and water 
in the vicinity of an abandoned e-waste recycling site: Implications for dissemination of heavy metals. Science of the Total Environment, 506, 217, 2015.

25. EL-RJOOB A.W.O., MASSADEH A.M., OMARI M.N. Evaluation of $\mathrm{Pb}, \mathrm{Cu}, \mathrm{Zn}, \mathrm{Cd}, \mathrm{Ni}$ and $\mathrm{Fe}$ levels in Rosmarinus officinalis labaiatae (Rosemary) medicinal plant and soils in selected zones in Jordan. Environmental Monitoring and Assessment, 140 (1-3), 61, 2008.

26. CHEN H.Y., YUAN X.Y., LI T.Y., HU S., JI J.F., WANG C. Characteristics of heavy metal transfer and their influencing factors in different soil-crop systems of the industrialization region, China. Ecotoxicology and Environmental Safety, 126, 193, 2016.

27. GASIOREK M., KOWALSKA J., MAZUREK R., PAJAK M. Comprehensive assessment of heavy metal pollution in topsoil of historical urban park on an example of the Planty Park in Krakow (Poland). Chemosphere, 179, 148, 2017.

28. LEE C.S., LI X.D., SHI W.Z., CHEUNG S.C., THORNTON I. Metal contamination in urban, suburban, and country park soils of Hong Kong: A study based on GIS and multivariate statistics. Science of the Total Environment, 356 (1-3), 45, 2006.

29. SUN Y.B., ZHOU Q.X., XIE X.K., LIU R. Spatial, sources and risk assessment of heavy metal contamination of urban soils in typical regions of Shenyang, China. Journal of Hazardous materials, 174 (1-3), 455, 2010.

30. TEPANOSYAN G., SAHAKYAN L., BELYAEVA O., MAGHAKYAN N., SAGHATELYAN A. Human health risk assessment and riskiest heavy metal origin identification in urban soils of Yerevan, Armenia. Chemosphere, 184, 1230, 2017.

31. XIAO Q., ZONG Y.T., LU S.G. Assessment of heavy metal pollution and human health risk in urban soils of steel industrial city (Anshan), Liaoning, Northeast China. Ecotoxicology and Environmental Safety, 120, 377, 2015.

32. PAN S.H., WANG K.Y., WANG L., WANG Z.B., HAN Y.Y. Risk Assessment System Based on WebGIS for Heavy Metal Pollution in Farmland Soils in China. Sustainability, 9 (10), 2017.

33. USEPA. Superfund Public Health Evaluation Manual; EPA/540/186060; Environmental Protection Agency: Washington, DC, USA, 1986.

34. USEPA. Risk Assessment Guidance for Superfund Volume I Human Health Evaluation Manual (Part A); EPA/540/189/002; Environmental Protection Agency: Washington, DC, USA, 1989

35. USEPA. Risk Assessment Guidance for Superfund Volume III Part A, Process for Conducting Probabilistic Risk Assessment; EPA/540/R-02/002; Environmental Protection Agency: Washington, DC, USA, 2001.

36. WEI X., GAO B., WANG P., ZHOU H.D., LU J. Pollution characteristics and health risk assessment of heavy metals in street dusts from different functional areas in Beijing, China. Ecotoxicology and Environmental Safety, 112, 186, 2015.

37. CHABUKDHARA M., NEMA A.K. Heavy metals assessment in urban soil around industrial clusters in Ghaziabad, India: Probabilistic health risk approach. Ecotoxicology and Environmental Safety, 87, 57, 2013.

38. CHEN H.Y., TENG Y.G., LU S.J., WANG Y.Y., WANG J.S. Contamination features and health risk of soil heavy metals in China. Science of the Total Environment, 512, 143, 2015.

39. ZHANG X.Y., ZHONG T.Y., LIU L., OUYANG X.Y. Impact of Soil Heavy Metal Pollution on Food Safety in China. Plos One, 10 (8), 118, 2015.
40. WU S., PENG S.Q., ZHANG X.X., WU D.L., LUO W. ZHANG T.B., ZHOU S.G., YANG G.Y., WAN H.F., WU L.Q. Levels and health risk assessments of heavy metals in urban soils in Dongguan, China. Journal of Geochemical Exploration, 148, 71, 2015.

41. LI F., HUANG J.H., ZENG G.M., LIU W.C., HUANG X.L., HUANG B., GU Y.L., SHI L.X., HE X.X., HE Y. Toxic metals in topsoil under different land uses from Xiandao District, middle China: distribution, relationship with soil characteristics, and health risk assessment. Environmental Science and Pollution Research, 22 (16), 12261, 2015.

42. USEPA. Exposure Factors Handbook 2011 Edition (Final Report); EPA/600/R-09/052F; Environmental Protection Agency: Washington, DC, USA, 2011.

43. LI L.Y., ZHANG Y.R., WANG J.Z., CHEN C., ZANG Y.M., WANG P.Y. Investigation on Dietary Consumption of Different Categories of Food Among 3-12 Year Old Children in China. Food and Nutrition in China, 20, 78, 2014 [In Chinese].

44. WANG Z., LIU S.Q., CHEN X.M., LIN C.Y. Estimates of the Exposed Dermal Surface Area of Chinese in View of Human Health Risk Assessment.Journal of Safety and Environment, 8 (4), 152, 2008 [In Chinese].

45. USEPA. Risk-based Concentration Table; Environmental Protection Agency: Philadelphia, PA, USA, 2011.

46. Integrated Risk Information System. Available online: https://cfpub.epa.gov/ncea/iris drafts/atoz.cfm?list type $=$ alpha (accessed on 28 June 2019)

47. SHAO F.S., ZHOU H.Y. Background value of soil environment in Henan Province. Henan Agriculture, 10, 29, 1998 [In Chinese].

48. LI X.Y., LI Z.G., LIN C.J., BI X.Y., LIU J.L., FENG X., ZHANG H., CHEN J., WU T.T. Health risks of heavy metal exposure through vegetable consumption near a large-scale $\mathrm{Pb} / \mathrm{Zn}$ smelter in central China. Ecotoxicology and Environmental Safety, 161, 99, 2018.

49. WEI C.Y., WANG C., YANG L.S. Characterizing spatial distribution and sources of heavy metals in the soils from mining-smelting activities in Shuikoushan, Hunan Province, China. Journal of Environmental Sciences, 21 (9), 1230, 2009.

50. FU S., WEI C.Y. Multivariate and spatial analysis of heavy metal sources and variations in a large old antimony mine, China. Journal of Soils and Sediments, 13 (1), 106, 2012.

51. BARKETT M.O., AKüN E. Heavy metal contents of contaminated soils and ecological risk assessment in abandoned copper mine harbor in Yedidalga, Northern Cyprus. Environmental Earth Sciences, 77, 2018.

52. DENG Y., JIANG L., XU L., HAO X., ZHANG S., XU M., ZHU P., FU S., LIANG Y., YIN H., LIU X., BAI L., JIANG H., LIU H. Spatial distribution and risk assessment of heavy metals in contaminated paddy fields - A case study in Xiangtan City, southern China. Ecotoxicology and Environment Safety, 171, 281, 2019.

53. NAWAB J., KHAN S., SHAH M.T., KHAN K., HUANG Q., ALI R. Quantification of Heavy Metals in Mining Affected Soil and Their Bioaccumulation in Native Plant Species. International Journal of Phytoremediation, 17, 801, 2015.

54. ZHANG Z.M., ZHANG Q.H., TU C.L., ZHANG J.C., LIN C.H., FANG H., WEN X.M. Effects on heavy metal in Karst Region Soil and the enrichment characteristics of rice-rape rotation. Polish of Journal Environmental Studies, 28 (6), 4485, 2019. 
55. PAN L.B., WANG Y., MA J., HU Y., SU B.Y., FANG G.L., WANG L., XIANG B. A review of heavy metal pollution levels and health risk assessment of urban soils in Chinese cities. Environmental Science and Pollution Research, 25 (2), 1055, 2018.
56. TANG J.X., HE M.M., LUO Q., ADEEL M., JIAO F. Heavy metals in agricultural soils from a typical mining city in China: spatial distribution, source apportionment, and health risk assessment. Polish of Journal Envrionmental Studies, 29 (2), 1, 2020 